\title{
Effectiveness of Windstorm-Producing Thunderstorms Early Warning Issues in Peninsular Malaysia
}

\author{
Mohd Fairuz Bachok, Supiah Shamsudin, and Roslan Zainal Abidin
}

\begin{abstract}
The study is intended to evaluate the accuracy of windstorm-producing thunderstorms issued warning by Malaysia Meteorological Department (METMalaysia) in Peninsular Malaysia. Besides, the study also evaluate information which been analysed from thunderstorms warning either can be used as an indicator to know the risks of windstorm-producing thunderstorms. Findings from the study show that existing mechanism that been used in Peninsular Malaysia for detect and forecast windstorm-producing thunderstorms generally ineffective or specifically effective to detect thunderstorm occurrence but not to detect and forecast thunderstorm by-products especially strong winds. Information analysed from thunderstorms warning also is not significant to be use an indicator to know the possibility of windstorm-producing thunderstorms occurrence and identify the districts which prone to be experience of this disaster.
\end{abstract}

Index Terms-Effective, Peninsular Malaysia, warning, windstorm-producing thunderstorms.

\section{INTRODUCTION}

Thunderstorms are capable of producing hail, heavy rain, frequent lightning, and strong gusty winds. The strong winds can reach high speeds causing significant damage. Roof blown away, objects become airborne, and uprooted tree are the few examples which could extend to cause secondary damage such as buildings collapse, injury, and losses to life of the humans or even animals. The victims is not only incurring losses but some of them may suffer from phobia especially during bad weather. This event frequently occurs when a cluster of thunderstorms affect an area for a prolonged period of time [1]. Therefore, there is why windstorm early warning system was developed, so that the public can prepare for the possibility of this natural disaster. Early warning with high accuracy will increase the public's trust to the issued warning, later prepare and take appropriate action but if the accuracy of the issued warning is low, it's will cause the opposite.

Malaysia also is no exception in experiencing this disaster. In Malaysia, according to the study of windstorm occurrences in the period of 2000-2012 found that windstorms can be expected each year, windstorm occurred throughout the year, most of the districts had experienced of windstorm and most

Manuscript received July 14, 2014; revised September 10, 2014.

Mohd Fairuz Bachok is with the Faculty of Civil Engineering, Universiti Teknologi MARA Cawangan Pahang, Pahang, Malaysia (e-mail: mohdfairuz@pahang.uitm.edu.my).

Supiah Shamsudin is with the Razak School of Engineering and Advanced Technology, Universiti Teknologi Malaysia, Kuala Lumpur, Malaysia (e-mail: supiah@ic.utm.edu.my).

Roslan Zainal Abidin is with the School of Engineering and Technology Infrastructure, Infrastructure University Kuala Lumpur, Selangor, Malaysia (e-mail: roslan@iukl.edu.my). of the windstorms had short time of life cycle which last less than 30 minutes [2]. Early warning related to the windstorm in Malaysia is monitored by the METMalaysia. METMalaysia used Doppler radar and FY-2E satellite as a tool in identifying areas (districts) which are likely to experience heavy rain and thunderstorms. As an example, a district is forecasted to be experience heavy rains, thunderstorms, and the possibility of strong winds within a certain period of time if the radar imagery shows heavy rain color coded of the cloud cluster and satellite imagery shows there is a convective clouds in the district. Not all thunderstorms that been detected will be issued a warning. Weak thunderstorm which lasted less than an hour and occur only in a small area is not considered because it did not meet the criteria for a thunderstorm warning. After the warning has been issued, METMalaysia will continuously monitoring and follow it up periodically. Through the time, the issued warning will be only updated when convective clouds intensified or moved to another districts. They also will let the public know that the threat of heavy rain and thunderstorms were over after the convective clouds had dissipated. The thunderstorm and heavy rain warning disseminated to the public is through department website, Facebook, and Twitter.

However, remarks 'these conditions may cause strong winds' (Appendix A) for some thunderstorm warnings has raised questions of the windstorm-producing thunderstorms issued warnings accuracy because term 'may' can mean either a tendency do occur or not do occur. As a result, existing mechanism of issued warning accuracy should be evaluated in order to know its effectiveness. Satisfactory, the existing mechanism should be maintained but if the result showed otherwise, the enhancements must be done to the existing mechanism in the future.

Besides, opinion of several authors which commented about lack of mechanism to predict windstorm-producing thunderstorms in the country and no study been carried out until to-date on the effectiveness of existing mechanism in issued warning of windstorm-producing thunderstorms are the others reasons why this evaluation is essential. Malaysia has made significant progress on technical aspects of monitoring and forecasting heavy rainfall during the Northeast monsoon but when deals with the windstorm especially on wind gust prediction, this aspects still lack of capability and provision of timely and accurate early warning on strong winds to the users with sufficient lead time, its intensity, and damages [1], [3], [4]. In fact, Malaysia frequently experience windstorm throughout the year and at almost districts.

An effective early warning system is the system that has high accuracy of the prediction that will lead to the high percentage of the correct warning. The false and miss alarm 
should be avoid or unless minimise since it will reflect the credibility of the system. It does not just erode public reliability to the system but also wasted time, effort, and resources. Moreover, create dilemma to the operator where they are often criticized due to a missed and erroneous warnings but infrequently praised if made a correct warnings [5]. So, attention should be given at the early stage of the storm prediction. The good storm occurrence at the surface prediction algorithms should utilize image processing, artificial intelligence, neural networks, expert system, and fuzzy logic techniques [6]. The indicators from radar or even satellite alone is not sufficient but should be supported by ground-truth observations. Even though radar or satellite provides more lead time with accurate information on the potential location, however without the ground-truth observations, the credibility is lower since radar and satellite measurements are above ground [7].

\section{Methodology}

Research design for the study divided into three (3) objectives to be evaluated which are:

1) Accuracy of windstorm-producing issued warning

2) Number of warned districts could be an indicator to know that the windstorm-producing thunderstorms do occur or do not occur

3) Number of warning received by a district can be an indicator that the districts is prone to be experienced of the occurrence of windstorm-producing thunderstorms or more risk compared to other districts or otherwise.

TABLE I: DETAILS OF THE STUDY

\begin{tabular}{cc}
\hline \hline Details & Remarks \\
\hline Period & January - June 2013 (6 months) \\
Location & Peninsular Malaysia \\
States (no.) & 12 \\
Districts (no.) & 87 \\
Warnings (no.) & 290 \\
Warnings per districts (no.) & 5024 \\
Windstorm occurrences (no.) & 91 \\
\hline \hline
\end{tabular}

TABLE II: DETAILS OF TIME PERIOD

\begin{tabular}{cc}
\hline \hline Time & Remarks \\
\hline $00.59 \mathrm{am} / 00.59$ & Midnight \\
$03.59 \mathrm{am} / 03.59$ & Early morning \\
$05.59 \mathrm{am} / 06.59$ & Dawn \\
$09.59 \mathrm{am} / 09.59$ & Morning \\
$11.59 \mathrm{am} / 11.59$ & Late morning \\
$01.59 \mathrm{pm} / 13.59$ & Noon \\
$03.59 \mathrm{pm} / 15.59$ & Early afternoon \\
$05.59 \mathrm{pm} / 17.59$ & Afternoon \\
$06.59 \mathrm{pm} / 18.59$ & Late afternoon \\
$07.59 \mathrm{pm} / 19.59$ & Evening \\
$08.59 \mathrm{pm} / 20.59$ & Early night \\
$10.59 \mathrm{pm} / 22.59$ & Night \\
$11.59 \mathrm{pm} / 23.59$ & Late night \\
\hline \hline
\end{tabular}

Table I shows the details of the study. Warning represents a warning which issued throughout January 1st, till June 30th, 2013. Even though sometimes in a day, there are three (3) times warning, it is still counted as three times instead of once. On the other hand, number of warning counted actually refers to the frequencies instead of day. While, warnings per districts refers to the warning for each district. For example, if a date which there is three (3) times of warnings in the day, first and second warning issued to the district but not the third warning, so it means warning per districts for district on that particular date is two (2). Just a thunderstorm warning which has remarks 'these conditions may cause strong winds' only will be considered.

Information in thunderstorm warning and details of windstorm occurrences are the main materials of the study. Thunderstorm warnings were collected from METMalaysia website, and Facebook. Date, duration (start and end time) of warning, and warned districts are the information that need to be gathered from thunderstorm warnings (Appendix B). Since end time of warning using terms like early morning, late morning etc. and not mentioning time, thus the terms is converted to specific time (Table II). This is intended to make easier and accurate matching between period of warning and time of windstorm occurrence.

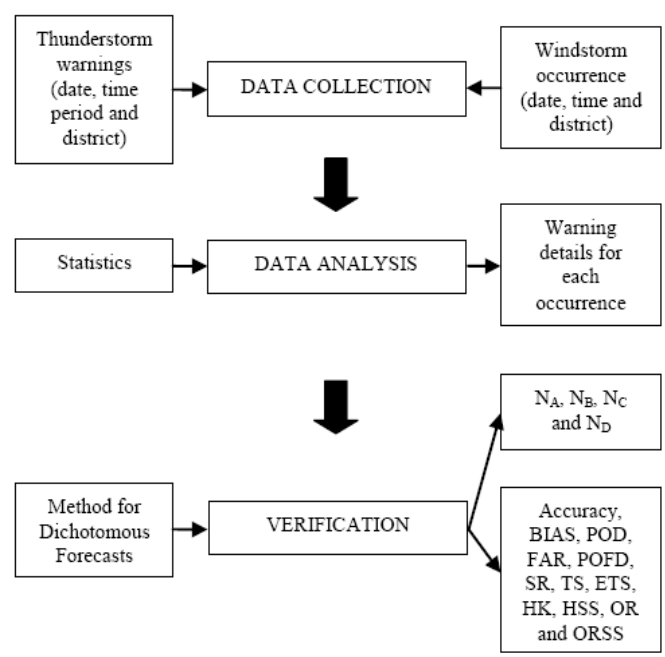

Fig. 1. Step by step of first evaluation.

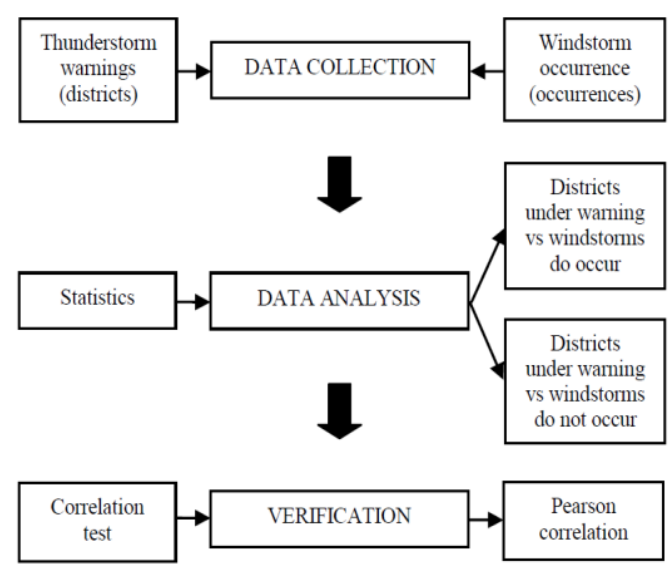

Fig. 2. Step by step of second evaluation.

While details of windstorm occurrences collected through reports from the Department of Social Welfare (DSW) database, and mass media. Windstorm occurrence can only be considered as a case if its causes the damage such as blown roofs, uprooted trees, etc. The information gathered include date, time, and location (district) of occurrence. DSW is a government agency that responsible to assess public property damage due to natural disasters and subsequently provide financial assistance to the victim.

Details of warnings and windstorm occurrences for each districts, later be compared. The forecast verification of windstorm-producing thunderstorms issued warnings is 
applied by using Standard Verification Methods for Dichotomous Forecasts [8].

Fig. 1, Fig. 2, and Fig. 3 shows step by step how the accuracy of windstorm-producing thunderstorms issued warning be evaluated and relationship between two (2) parameters analysed from information in thunderstorm warning with the risk of windstorm.

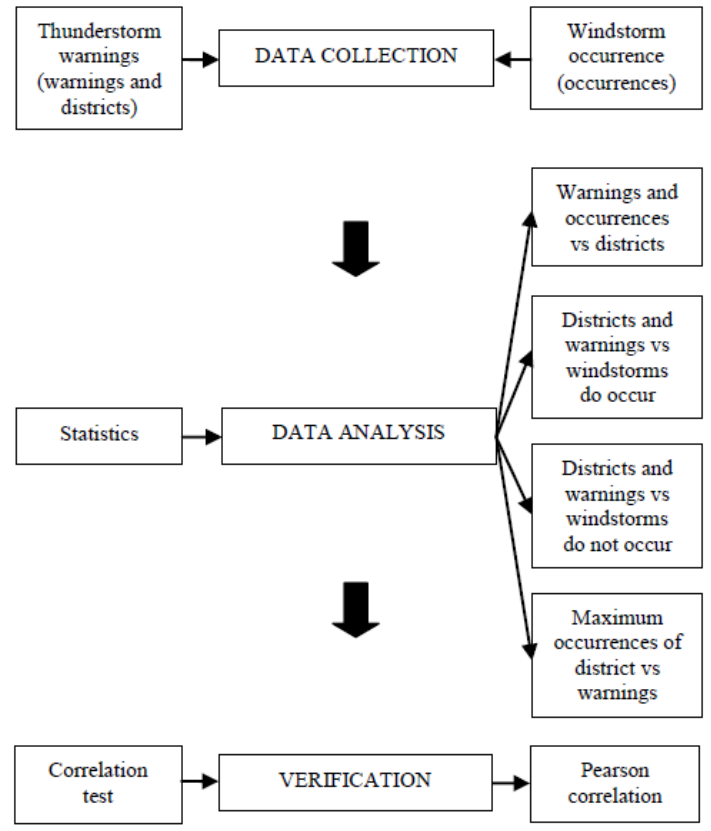

Fig. 3. Step by step of third evaluation.

\section{STANDARD VERIFICATION METHODS OF Dichotomous FORECAST}

Methods of Dichotomous Forecast has been widely used for forecasts or warnings verification of meteorological phenomena such as rain, floods, tornado, frosts, fogs, etc. either do occur or do not occur [9]. This kind of verification method also known as yes/no forecasts because its present simplest type of forecasting and decision-making situation which possible outcomes for an event can be summarized as shown in the Table III. While Table IV shows the details of each equations in this method. This method is still been used until now in meteorological forecasts and warnings (see examples: [10]-[14]), even though it was first used in 1884 to verify tornado predictions.

TABLE III: CONTINGENCY TABLE

\begin{tabular}{ccccc}
\hline \hline \multicolumn{5}{c}{ Observed } \\
\hline \multirow{3}{*}{ Forecast } & Yes & No & Total \\
& Yes & $\mathrm{N}_{\mathrm{A}}$ & $\mathrm{N}_{\mathrm{C}}$ & forecast yes \\
& No & $\mathrm{N}_{\mathrm{B}}$ & $\mathrm{N}_{\mathrm{D}}$ & forecast no \\
& Total & observed yes & observed no & Total \\
\hline \hline
\end{tabular}

where

Hits, $N_{A}=$ event forecast to occur and did occur

Misses, $N_{B}=$ event forecast not to occur but did occur

False alarms, $N_{C}=$ event forecast to occur but did not occur

Correct negatives, $N_{D}=$ event forecast not to occur and did not occur

$$
\begin{gathered}
\text { Accuracy }(\text { fraction correct })=\frac{N_{A}+N_{D}}{\text { total }} \\
\text { Bias score (frequency bias) }=\frac{N_{A}+N c}{N_{A}+N_{B}} \\
\text { Probability of detection (hit rate) }=\frac{N_{A}}{N_{A}+N_{B}}
\end{gathered}
$$

$$
\text { False alarm ratio }=\frac{N c}{N_{A}+N_{C}}
$$

$$
\text { Success ratio }=\frac{N_{A}}{N_{A}+N_{C}}
$$

Threat score (critical success index $)=\frac{N_{A}}{N_{A}+N_{B}+N_{C}}$

Equitable threat score (Gilbert skill score)

$$
=\frac{N_{A}-\text { NArandom }}{N_{A}+N_{B}+N_{C}-N_{\text {Arandom }}}
$$

where $N_{\text {Arandom }}=\frac{\left(N_{A}+N_{B}\right)\left(N_{A}+N_{C}\right)}{\text { total }}$

Hanssen and Kuipers discriminant (true skill statistic,

$$
\text { Peirce's skill scor }=\frac{N_{A}}{N_{A}+N_{B}}-\frac{N_{C}}{N_{C}+N_{D}}
$$

Heidke skill score (Cohen's K)

$$
=\frac{\left(N_{A}+N_{D}\right)-(\text { expectedcorrect })_{\text {random }}}{\text { total }-(\text { expectedcorrect })_{\text {random }}}
$$

where $(\text { expected correct })_{\text {random }}=$ $\underline{\left(N_{A}+N_{B}\right)\left(N_{A}+N_{C}\right)+\left(N_{D}+N_{B}\right)\left(N_{D}+N_{C}\right)}$

$$
\begin{aligned}
& \text { total } \\
& \text { Odds ratio }=\frac{N_{A} * N_{D}}{N_{B} * N_{C}}
\end{aligned}
$$

Odds ratio skill score (Yule's Q) =

$$
\frac{\left(N_{A} * N_{D}\right)-\left(N_{D} * N_{C}\right)}{\left(N_{A} * N_{D}\right)+\left(N_{B} * N_{C}\right)}
$$

\section{REsults}

An early warning of natural disasters is essential because the issued warning in advance of a predicted possibility of disaster occurs will assists public with adequate time to make early preparations to prevent or unless minimize the adverse effects of these disasters. However, if the warnings is issued but the disasters do not occur will also cause public perceptions of the warnings begin to erode and if this continuous happens, an issued warning is no longer to be trusted. Without warning it's could be a problem because public are not able to take precautionary measures and as a result, it is likely public will experience greater damage if disaster occur. The most important, the warnings must be equipped with optimum lead time because it's make the 
issued warnings to be taken seriously by public who then respond effectively. Optimum time means that people have adequate time to prepare for disasters which not too early or too late from predicted occurrence. Besides, warnings that make public always put as priority and taken seriously.
Usable warning lead time is useful if those at risk have enough time to decide how to react which should not too late because public might not have time to take useful reaction or too early because public might feel not deem it urgent enough to be concern that issued warning should be merit [5].

TABLE IV: DETAILS OF METHODS FOR DICHOTOMOUS FoRECAST

\begin{tabular}{|c|c|c|c|c|}
\hline Equation & Abbreviation & Range & Perfect score & Answers the question \\
\hline Accuracy (fraction correct) & Accuracy & 0 to 1 & 1 & What fraction of the forecasts were correct? \\
\hline Bias score (frequency bias) & BIAS & 0 to $\infty$ & 1 & $\begin{array}{l}\text { How did the forecast frequency of "yes" events compare to the } \\
\text { observed frequency of "yes" events? }\end{array}$ \\
\hline False alarm ratio & FAR & 0 to 1 & 0 & $\begin{array}{l}\text { What fraction of the predicted "yes" events actually did not occur } \\
\text { (i.e., were false alarms)? }\end{array}$ \\
\hline $\begin{array}{l}\text { Probability of false detection (false } \\
\text { alarm rate) }\end{array}$ & POFD & 0 to 1 & 0 & $\begin{array}{l}\text { What fraction of the observed "no" events were incorrectly forecast } \\
\text { as "yes"? }\end{array}$ \\
\hline Success ratio & SR & 0 to 1 & 1 & What fraction of the forecast "yes" events were correctly observed? \\
\hline Threat score (critical success index) & TS & 0 to 1 & 1 & $\begin{array}{l}\text { How well did the forecast "yes" events correspond to the observed } \\
\text { "yes" events? }\end{array}$ \\
\hline $\begin{array}{l}\text { Equitable threat score (Gilbert skill } \\
\text { score) }\end{array}$ & ETS & $\begin{array}{l}-0.33 \\
\text { to } 1\end{array}$ & 1 & $\begin{array}{l}\text { How well did the forecast "yes" events correspond to the observed } \\
\text { "yes" events (accounting for hits due to chance)? }\end{array}$ \\
\hline $\begin{array}{l}\text { Hanssen and Kuipers discriminant } \\
\text { (true skill statistic, Peirce's skill score) }\end{array}$ & $\mathrm{HK}$ & -1 to 1 & 1 & $\begin{array}{l}\text { How well did the forecast separate the "yes" events from the "no" } \\
\text { events? }\end{array}$ \\
\hline Heidke skill score (Cohen's K) & HSS & $-\infty$ to 1 & 1 & $\begin{array}{l}\text { What was the accuracy of the forecast relative to that of random } \\
\text { chance? }\end{array}$ \\
\hline Odds ratio & OR & 1 to $\infty$ & $\infty$ & $\begin{array}{l}\text { What is the ratio of the odds of a "yes" forecast being correct, to the } \\
\text { odds of a "yes" forecast being wrong? }\end{array}$ \\
\hline Odds ratio skill score (Yule's Q) & ORSS & -1 to 1 & 1 & What was the improvement of the forecast over random chance? \\
\hline
\end{tabular}

TABLE V: FORECAST VERIFICATION ANALYSIS USING METHODS FOR DiCHOTOMOUS FORECASTS

\begin{tabular}{|c|c|c|c|c|}
\hline Parameters & Perfect score & Minimum & Maximum & Average \\
\hline $\mathrm{N}_{\mathrm{A}}$ & - & 0 & 4 & 0 \\
\hline $\mathrm{N}_{\mathrm{B}}$ & - & 0 & 7 & 1 \\
\hline $\mathrm{N}_{\mathrm{C}}$ & - & 21 & 98 & 58 \\
\hline $\mathrm{N}_{\mathrm{D}}$ & - & 102 & 164 & 135 \\
\hline Accuracy & 1 & 0.5303 & 0.8859 & 0.7025 \\
\hline BIAS & 1 & 0 & 94 & 39 \\
\hline POD & 1 & 0 & 1 & 0.2539 \\
\hline FAR & 0 & 0.9565 & 1 & 0.9954 \\
\hline POFD & 0 & 0.1141 & 0.4697 & 0.2954 \\
\hline SR & 1 & 0 & 0.0435 & 0.0046 \\
\hline TS & 1 & 0 & 0.0426 & 0.0046 \\
\hline ETS & 1 & 0 & 0.1247 & 0.0126 \\
\hline HK & 1 & -0.4476 & 0.8054 & -0.06 \\
\hline HSS & 1 & -0.067 & 0.0426 & -0.0015 \\
\hline OR & $\infty$ & 0 & 4.8602 & 0.7439 \\
\hline ORSS & 1 & -1 & 1 & -0.3985 \\
\hline
\end{tabular}

TABLE VI: ANALYSIS OF WINDSTORM-PRODUCING THUNDERSTORMS ISSUED WARNINGS FOR 91 WINDSTORM OCCURRENCES WITHIN STUDY PERIOD

\begin{tabular}{|c|c|c|c|}
\hline \multirow{2}{*}{ Warning alarms } & \multirow{2}{*}{ Period } & \multicolumn{2}{|c|}{ Windstorm occurrences } \\
\hline & & (no.) & $(\%)$ \\
\hline \multirow{8}{*}{$\begin{array}{c}\text { Correct warning (within estimation time period before } \\
\text { windstorm occurrence) }\end{array}$} & After $<15$ minutes & 5 & 5.5 \\
\hline & After 15 minutes & 5 & 5.5 \\
\hline & After 30 minutes & 7 & 7.7 \\
\hline & After 45 minutes & 3 & 3.3 \\
\hline & After 1 hours & 6 & 6.6 \\
\hline & After 2 hours & 2 & 2.2 \\
\hline & After 3 hours & 2 & 2.2 \\
\hline & Total & 30 & 33.0 \\
\hline \multirow{8}{*}{ False warning (warning been issued after windstorm occurred) } & After $<15$ minutes & 6 & 6.6 \\
\hline & After 15 minutes & 5 & 5.5 \\
\hline & After 30 minutes & 3 & 3.3 \\
\hline & After 45 minutes & 3 & 3.3 \\
\hline & After 1 hours & 7 & 7.7 \\
\hline & After 2 hours & 4 & 4.4 \\
\hline & After 3 hours & 7 & 7.7 \\
\hline & Total & 35 & 38.5 \\
\hline \multirow{8}{*}{$\begin{array}{l}\text { False warning (warning been issued before windstorm } \\
\text { occurred which is after warning estimation time period) }\end{array}$} & Before $<15$ minutes & & \\
\hline & Before 15 minutes & & \\
\hline & Before 30 minutes & & \\
\hline & Before 45 minutes & & \\
\hline & Before 1 hours & 1 & 1.1 \\
\hline & Before 2 hours & & \\
\hline & Before 3 hours & & \\
\hline & Total & 1 & 1.1 \\
\hline False warning (no warning been issued on that day) & Total & 25 & 27.4 \\
\hline
\end{tabular}


International Journal of Environmental Science and Development, Vol. 6, No. 9, September 2015

TABLE VII: ANALYSIS OF WARNED DISTRICTS

\begin{tabular}{ccccc}
\hline \hline Districts under warnings (no.) & \multicolumn{2}{c}{ Windstorms do occur } & \multicolumn{2}{c}{ Windstorms do not occur } \\
\cline { 2 - 5 } & (no.) & $(\%)$ & $($ no.) & $(\%)$ \\
\cline { 2 - 5 } & 1 & 0.3 & 24 & 8.3 \\
$6-10$ & 4 & 1.4 & 62 & 21.4 \\
$11-15$ & 4 & 1.4 & 57 & 19.7 \\
$16-20$ & 2 & 0.7 & 36 & 12.4 \\
$21-25$ & 5 & 1.7 & 41 & 6.2 \\
$26-30$ & 1 & 0.3 & 18 & 3.5 \\
$31-35$ & 1 & 0.3 & 10 & 3.5 \\
$36-40$ & 3 & 1.0 & 10 & 0.3 \\
$41-45$ & 2 & 0.7 & 1 & 0.3 \\
$46-50$ & 1 & 0.3 & 3 & 1.0 \\
$51-55$ & 1 & 0.3 & 2 & 0.7 \\
$56-60$ & 0 & 0.0 & 265 & 91.4 \\
Total & 25 & 8.6 & &
\end{tabular}

TABLE VIII: ANALYSIS OF WARNINGS

\begin{tabular}{ccccc}
\hline \hline Warnings (no.) & \multicolumn{2}{c}{ Districts (windstorms do occur) } & \multicolumn{2}{c}{ Districts (windstorms do not occur) } \\
\cline { 2 - 5 } & $($ no.) & $(\%)$ & 0 & $($ (no.) \\
\hline 10 & 0 & 0.0 & 0 & 0.0 \\
$11-20$ & 0 & 0.0 & 10 & 0.0 \\
$31-40$ & 2 & 2.3 & 4 & 5 \\
$41-50$ & 5 & 5.8 & 9 & 5.6 \\
$51-60$ & 8 & 10.3 & 1 & 10.3 \\
$61-70$ & 9 & 8.1 & 2 & 1.2 \\
$71-80$ & 7 & 4.6 & 4 & 2.3 \\
$91-90$ & 4 & 8.1 & 5 & 4.6 \\
$91-100$ & 7 & 5.8 & 5.8 \\
\hline \hline
\end{tabular}

TABLE IX: ANALYSIS OF WARNINGS PER DISTRICT

\begin{tabular}{|c|c|c|c|c|c|c|c|}
\hline \multirow{2}{*}{$\begin{array}{l}\text { Warnings } \\
\text { (no.) }\end{array}$} & \multirow{2}{*}{$\begin{array}{l}\text { Windstorm occurrences } \\
\text { (no.) }\end{array}$} & \multicolumn{2}{|c|}{ Districts } & \multirow{2}{*}{$\begin{array}{l}\text { Warnings } \\
\text { (no.) }\end{array}$} & \multirow{2}{*}{$\begin{array}{l}\text { Windstorm occurrences } \\
\text { (no.) }\end{array}$} & \multicolumn{2}{|c|}{ Districts } \\
\hline & & (no.) & $(\%)$ & & & (no.) & $(\%)$ \\
\hline \multirow{8}{*}{$<10$} & 0 & & & \multirow{8}{*}{$51-60$} & 0 & 9 & 10.3 \\
\hline & 1 & & & & 1 & 5 & 5.8 \\
\hline & 2 & & & & 2 & 3 & 3.5 \\
\hline & 3 & & & & 3 & 1 & 1.2 \\
\hline & 4 & & & & 4 & & \\
\hline & 5 & & & & 5 & & \\
\hline & 6 & & & & 6 & & \\
\hline & 7 & & & & 7 & & \\
\hline \multirow{8}{*}{$11-20$} & 0 & & & \multirow{8}{*}{$61-70$} & 0 & 1 & 1.2 \\
\hline & 1 & & & & 1 & 5 & 5.8 \\
\hline & 2 & & & & 2 & 1 & 1.2 \\
\hline & 3 & & & & 3 & & \\
\hline & 4 & & & & 4 & & \\
\hline & 5 & & & & 5 & 1 & 1.2 \\
\hline & 6 & & & & 6 & & \\
\hline & 7 & & & & 7 & & \\
\hline \multirow{8}{*}{$21-30$} & 0 & 10 & 11.5 & \multirow{8}{*}{$71-80$} & 0 & 2 & 2.3 \\
\hline & 1 & 2 & 2.3 & & 1 & 1 & 1.2 \\
\hline & 2 & & & & 2 & 1 & 1.2 \\
\hline & 3 & & & & 3 & & \\
\hline & 4 & & & & 4 & & \\
\hline & 5 & & & & 5 & 2 & 2.3 \\
\hline & 6 & & & & 6 & & \\
\hline & 7 & & & & 7 & & \\
\hline \multirow{8}{*}{$31-40$} & 0 & 4 & 4.6 & \multirow{8}{*}{$81-90$} & 0 & 4 & 4.6 \\
\hline & 1 & 3 & 3.5 & & 1 & 4 & 4.6 \\
\hline & 2 & 1 & 1.2 & & 2 & 3 & 3.5 \\
\hline & 3 & & & & 3 & & \\
\hline & 4 & & & & 4 & & \\
\hline & 5 & & & & 5 & & \\
\hline & 6 & & & & 6 & & \\
\hline & 7 & 1 & 1.2 & & 7 & & \\
\hline \multirow{8}{*}{$41-50$} & 0 & 5 & 5.8 & \multirow{8}{*}{$91-100$} & 0 & 5 & 5.8 \\
\hline & 1 & 4 & 4.6 & & 1 & 2 & 2.3 \\
\hline & 2 & 3 & 3.5 & & 2 & & \\
\hline & 3 & 1 & 1.2 & & 3 & 1 & 1.2 \\
\hline & 4 & & & & 4 & & \\
\hline & 5 & & & & 5 & & \\
\hline & 6 & & & & 6 & 2 & 2.3 \\
\hline & 7 & & & & 7 & & \\
\hline
\end{tabular}


In the context of windstorm-producing thunderstorms early warnings which issued by METMalaysia for Peninsular Malaysia show that existing mechanism for detect and forecast this disaster actually is ineffective. This is due to the most of the scale/index values of method to measure the forecast accuracy such as BIAS, POD, FAR, SR, TS, ETS, HK, HSS, OR, and ORSS is not close to the perfect score. Parameters of NA, NB, and Nc with high inaccuracy further supported this matter. The scale/index of Accuracy, POFD, and ND are the only parameters that showed better accuracy (Table V). On the other hand, existing mechanism to detect and forecast windstorm-producing thunderstorms is ineffective due to low accuracy even though ability of the mechanism to forecast event not do occur and did not occur is much better. However, the authors felt that forecast event not do occur and did not occur is less important aspect compare to forecast event do occur and did occur. Forecasting windstorm-producing thunderstorms precisely occur exactly is something more difficult than forecast of this disaster do not occur. This is due to the presence of convective clouds at an area does not necessarily will experience windstorm even during that time there is a thunderstorm. Thus, it's need in-depth and complex study to discriminate between convective clouds that produce strong wind or otherwise at that particular area. Forecast event not do occur and did not occur is opposite whereby it's much easier since it depending on present of convective clouds at an area. If there is no convective clouds, it can be concluded that the area won't be experienced of windstorm. Present of convective clouds at an area can be easily observed by examining satellite imageries. Obviously, the existing mechanism is effective to forecast or predict the occurrence of thunderstorm at an area but not thunderstorm by-products especially strong winds.

Table VI shows the details analysis of the windstorm-producing thunderstorms issued warnings for 91 windstorm occurrences within the study period. Even though $33.0 \%$ of the windstorm occurrences had been correctly warned, however if deducted by the percentage of the warning with impractical lead time and then compare with the false warning, the warning accuracy percentage is even lower. Practical warning lead time 2 to 4 hours before expected windstorm occurrence. What is more to be concern is the percentage warning issued after windstorm occurred is higher than the correctly warned and quit similar with no warning issued on the day of the windstorm occurred percentage. This indicate existing mechanisms is not just less efficient due to the low accuracy but lead time is impractical, issued after the windstorm occurred, and sometime no warning is given throughout the day on windstorm occurred.

Number of warned districts in a thunderstorms warning is not suitable as indicators for possibility of windstorm occur. An increasing number of warned districts means more numerous and extensive areas been covered by convective clouds, so indirectly it will increase the possibility of windstorm to be occurred. This approach is been used in existing mechanism that the presence of convective clouds is indicator of possibility thunderstorm occur and so on thunderstorm by-products. Table VII proves increasing number of warned districts does not consistent with increasing of windstorm occurrences whereby there is a lower number of warned districts but had a higher number of windstorm occurrences and vice versa. The inconsistency also been showed between number of warned districts with a number of windstorm do not occur during the issued warning period. This was reinforced by correlation value which equal to 0.102 which means there is no significant relationship since significant value is not less than 0.05 ( 2 tailed).

Number of warnings been warned to a district is evaluated because if the district frequently been warned means the district is prone to be experienced of windstorm occurrence due to the frequently presence of convective clouds at the particular district. Through evaluation shows that number of warnings is not suitable as indicator to know which district is prone of windstorm occurrence or in the other hand is more risk than the others. Analysis in Table VIII, Fig. 4 and Table IX prove this matter where number of warnings been warned to the district is not consistent with the number of windstorm occurrence at that district. It shown obviously inconsistency as the value of correlation which equal to 0.253 which is not within significant value less than 0.05 (2-tailed).

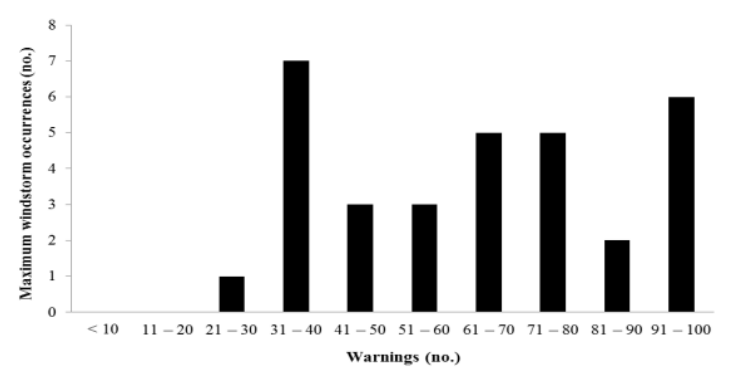

Fig. 4. Distribution graph of maximum windstorm occurrences for each range of warnings.

\section{CONCLUSION}

Existing mechanisms that been used in Peninsular Malaysia to detect and forecast windstorm-producing thunderstorms generally is ineffective. Moreover, false warning, no warning been issued for whole day even windstorm occurred on that day, warning been issued after windstorm occurred, and impractical lead time is at the high rate were the facts that need to be concern. Actually, existing mechanisms specifically effective to detect and forecast thunderstorm occurrence but not effective for thunderstorm by-products in this context refers to strong winds (windstorm). Action taken by METMalaysia by display remarks 'these conditions may cause strong winds' for some thunderstorm warning is a right action since there were windstorm occurrences within warning period even though it's very rare occasion. Besides, it's truth thunderstorm could produce strong winds in certain circumstances. The only concern is that public trust to the issued warning especially windstorm-producing thunderstorms will be eroded if no enhancement and improvement of the existing mechanism in the future.

Therefore, it is recommended that the existing mechanisms which able to detect thunderstorms occurrence should be maintained but in the same time, the mechanisms that specifically for detect and forecast windstorm-producing thunderstorms need to be developed which enhance the existing mechanisms. It can be concluded that mechanisms to detect, forecast, and issue warning for natural disaster must be always check its effectiveness because the accurate 
warnings can provide benefits to the public. Besides, it can assist in identifying weaknesses of existing mechanism and thus can be improved and enhanced in the future. It is critical especially in locations that experience frequent natural disasters.

Information that analysed from thunderstorm warning like number of warned districts, and number of warnings been warned to a district is not suitable to be an indicator to know whether presence of convective clouds will produce windstorm or not, and districts that prone of windstorm-producing thunderstorm occurrence. Both parameters been evaluated because the information can be directly obtained from thunderstorm warning. Obviously, existing mechanism is not just generally ineffective for windstorm-producing thunderstorms. The information in the thunderstorm also cannot be used as indicator to know the risk of windstorm in Peninsular Malaysia, and thus impractical as a part of risk management in the early planning of this natural disaster mitigation in the future. It should remember that effectiveness of an early warning system is measure by how the system work well (efficiently and effectively) to fulfill its designated functions [5].

\section{APPENDIX}

APPendix A: Remarks' These CONDITIONS May CAUSE STRONG Winds' IN THE THUNDERSTORM WARNING ISSUED BY METMALAYSIA

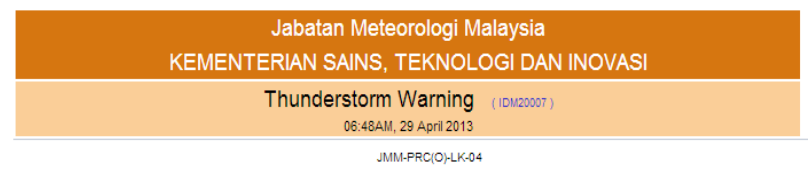

Our Ref. UMM.RMLO6701/10 JLD97(72)

Amaran Ribut Petir dan Hujan lebat

Dikeluarkan pada: 06:48am pada 29 April 2013

Ribut petir dan hujan lebat di negeri Sarawak: Bahagian Miri (Daerah Miri) dan Bintulu dijangka berterusan sehingga lewat pagi, Isnin 29 April 2013 Keadaan cuaca yang sama djangka berlaku di negeri Sarawak: Bahagian Mukah (Daerah Mukah) dan Sibu (Daerah Selangau).

Keadaan ini berkemungkinan menyebabkan angin kencang.

Thunderstorms and Heavy Rain Warning

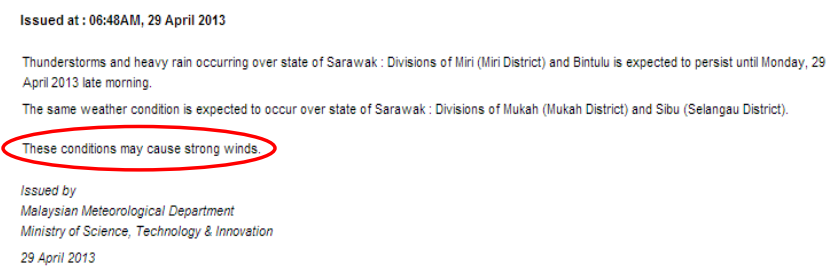

APPENDIX B: INFORMATION WHICH NEED TO BE GATHERED FROM THUNDERSTORMS WARNING

Thunderstorms and Heavy Rain Warning
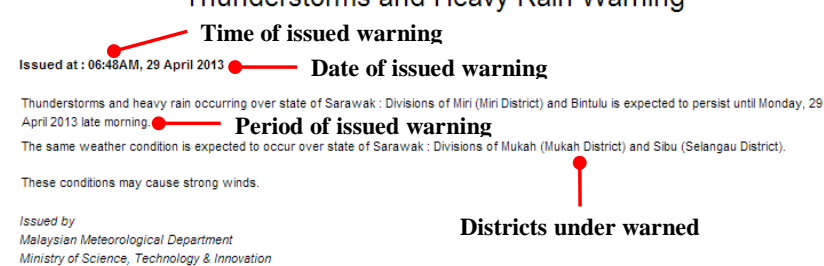

Districts under warned

29 April 2013

\section{ACKNOWLEDGMENT}

The authors would like to express their sincere thanks to Department of Social Welfare Malaysia, Putrajaya for their commitment and kindness in providing us a valuable data/information, Universiti Teknologi Malaysia (UTM) for the knowledge and technical experiences and Ministry of Education Malaysia for financial support.

\section{REFERENCES}

[1] K. C. Low, "Application of nowcasting techniques towards strengthening national warning capabilities on hydrometeorological and landslides hazards," in Proc. Public Weather Services Workshop on Warning of Real-time Hazards by Using Nowcasting Technology, Sydney, 2006.

[2] M. F. Bachok, S. Shamsudin, and R. Z. Abidin, "Windstorm Occurrences in Malaysia in the period of 2000-2012: An overview," in Proc. 1st ICSTSS Int. Conf., Kuantan, 2012.

[3] H. Hamdan, R. Zakaria, N. Lias, A. Taat, and S. F. M. Adam, "Extreme weather in Sarawak in 2009 (Translation Journals style)," in Proc. Malaysia Meteorological Department, 2010.

[4] A. K. Ibrahim, K. N. Ibrahim, N. K. Lai, and A. W. A. Razak, "Utilizing radar application in detection of possibility presence of hail with microburst according to Fujita scale (Translation Journals style)," Malaysia Meteorological Department, 2010.

[5] K. O. Salleh, "Early warning systems do's and don'ts in environmental hazard management," in Proc. Informal Regional Ministerial Consultation on Climate and Extreme Weather Impacts and Predictability, Kuala Lumpur, 2006.

[6] J. H. Golden and C. R. Adams, "The tornado problem: Forecast, warning and response," Natural Hazards Rev., vol. 1, no. 2, pp. 107-118, May 2000.

[7] J. Rauhala and D. M. Schultz, "Severe thunderstorm and tornado warnings in Europe," Atmos. Res., vol. 93, pp. 369-380, 2009.

[8] CAWCR. [Online]. Available: http://cawcr.gov.au/bmrc/wefor/staff/eee/verif/verif_web_page.html

[9] I. T. Jollife and D. B. Stephenson, Forecast Verification: A Practitioner's Guide in Atmospheric Science, England, British Library, 2003, pp. 37-73.

[10] A. Ishak, Z. M. Taib, N. H. Edros, M. H. Zamberi, and E. M. Fredericks, "Assessment impact of weather modification on local rainfall A case study in Muda agricultural development authority (MADA)," in Proc. Malaysia Meteorological Department, 2009.

[11] M. S. M. Yusof, K. K. Foo, and L. L. Kwok, "Performance of probability of detection (POD) and bias verification for WRF model,' in Proc. Malaysia Meteorological Department, 2013.

[12] J. Inampues, D. Aranguren, H. Torres, J. Montanya, I. Santoyo, E. Olarte, and C. Younes, "Analysis of lightning forecasts in Colombia based on the lightning detection network data," in Proc. 10th SIPDA Int. Symp., Curitiba, 2009.

[13] J. Lopez, E. Perez, J. Herrera, D. Aranguren, and L. Porras, "Thunderstorm warning alarms methodology using electric field mills and lightning location networks in mountainous regions," in Proc. ICLP Int. Conf., Vienna, 2012.

[14] N. Tartaglione, "Relationship between precipitation forecast errors and skill scores of dichotomous forecasts," Wea. Forecasting, vol. 25, pp 355-365, 2010.

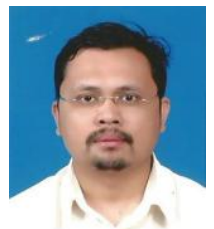

Mohd Fairuz Bachok was born in Johor, Malaysia in 1976. He is currently a postgraduate student toward his $\mathrm{Ph} . \mathrm{D}$ programme in civil engineering and major on climate engineering in Universiti Teknologi Malaysia, Malaysia. He received his B.Eng. (Hons) degree in civil and structural engineering in 1999 and M.Eng. degree in environment in 2000 from Universiti Kebangsaan Malaysia, Malaysia. $\mathrm{He}$ is a member of graduate engineer for Board of Engineer Malaysia (BEM). His current research interests include natural disaster, hydrology, hydraulics, risk assessment, artificial neural network model and information engineering.

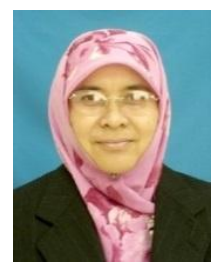

Supiah Shamsudin was born in Negeri Sembilan, Malaysia in 1960. She is currently an associate professor in the water resources and hydrology at the Department of Civil Engineering, Razak School of Engineering and Advanced Technology, UTM-IC, Malaysia. Her main specialization in particular is impounded water bodies multi-objective engineering. She received her bachelor of science (B.Sc.) degree in civil engineering from University of Miami, Coral Gables, Florida, USA in 1982, M.Sc. degree in civil engineering (hydraulics and water resources) from University of Nebraska-Lincoln, Nebraska, USA in 1992 and Ph.D degree in civil engineering from Universiti Teknologi 
Malaysia, Malaysia in 2003. The researches interests include intelligent detention pond design, watershed and reservoir management under uncertain environment, environmental hydrology, reservoir eutrophication, fuzzy and risk related approaches and multi-criteria decision support for water resources systems. She had published more than 20 papers. She is a member of International Water Association (IWA) London, graduate engineer for Board of Engineer Malaysia (BEM), International Association Hydrological Sciences (IAHS), International Association of Environmental Hydrology (IAEH), Malaysian Hydrological Society (MHS), Malaysian Water Association (MWA) and Malaysian Nano Association (MNA). She also has patent pending for Predicting Uncertainty of Sediment Loads, June 2010 and Fuzzy Approach to Forecast Phosphorus Loadings, December 2009. She wrote five books which are Uncertainty of Phosphorus Loadings Estimation Using Vollenweider Model For Reservoir Euthrophication Control, SelfAssessment Report for Accreditation of an Engineering Program, Structure For Architects and note book for 'Introduction to Hydrology and Introduction to Fluid Mechanics.

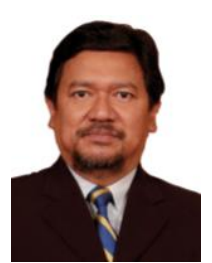

Roslan Zainal Abidin was born in Perak, Malaysia in 1958. He is currently a professor in School of Engineering and Technology Infrastructure, Infrastructure Universiti Kuala Lumpur, Malaysia. His main specialization in particular is in landslide and hydrological research. He received his advanced diploma in civil engineering from Institut Teknologi MARA, Malaysia in 1981, M.Sc. degree in agricultural engineering from Miyazaki University, Japan in 1989 and $\mathrm{Ph} . \mathrm{D}$ degree in Agricultural Engineering from Kagoshima University, Japan in 1992 . He was formerly the senior engineer at the Department of Irrigation and Drainage Malaysia for 15 years before he joined University Teknologi MARA, Malaysia in 1995 as a senior academic and researcher at the Faculty of Civil Engineering. He is the elected Malaysian representatives for the International Consortium on Landslides (ICL), research committee member for the International Hydrological Programm (IHP) Malaysia, editorial board for the Malaysian Construction Research Journal by the Construction Research Institute of Malaysia (CREAM), panel assessor for the Humid Tropic Centre for the Asia Pacific, active member of Malaysia National Committee on Irrigation and Drainage (MANCID) and the Malaysian Hydrological Society (MHS). He served as the Director of UiTM International Research Centre on Disaster Prevention (IRCDIP) from 2002 to 2010 . He has published more than 200 technical papers and produced 3 patented products which are related to environmental issues, particularly disaster forecasting and management. 